\title{
INTELLECTUAL PROPERTY IN BRAZIL: POSSIBILITIES AND ADVANCES
}

KEY WORDS: intellectual property, patent, research, innovation

\section{Júnior Mozart} Nogueira Gomes*

Federal Institute of Amazonas, Manoel Urbano Road, km 77 - Morada do Sol, Manacapuru - AM,Brazil, zip code 69400-000. *Corresponding Author

E $\quad$ Intellectual property is one of the main topics of our time. All organizations and companies that work with research and 0 innovation have intellectual property as one of the factors for economic and financial growth. Every day, many governments discover about the benefits of industrial innovation and how patents can defend new technologies. The purpose of this research is to report on intellectual property in Brazil. It is concluded that it is necessary to advance in policies, that Brazilian patents take a long time to be granted. Investments are needed so that companies in Brazil can learn about patent laws and benefit from them.

\section{INTRODUCTION}

The history of human civilization has always been marked by great innovations by great inventors. Isaac Newton, Benjamin Franklin, Santos Dumont and Thomas Edison, among others, are part of this team.

According to Erber (2004), it is impossible to imagine modern society without the advances that innovation has brought to health, medicine, technology, agriculture.

Organizations today need to reinvent themselves all the time. Large investments are made in people and new technologies. The word innovation has been used all over the world and in all sectors of modern society. It is linked to the competitiveness and survival of organizations, a fact that currently shows the need to train people who are increasingly creative and knowledgeable about innovative tools. (DA SILVA, et al, 2016).

According to Da Silva et al. (2020), innovation is considered a differential within organizations. All large companies invest in new products, new processes and services.

Factors such as globalization and easy access to information favor the dissemination of new ideas.

It takes more than an idea. It is necessary that a good idea can attract and retain customers. Win the market and become a necessary product or service for society. This is innovation.

\section{THE IMPORTANCE OF THE PATENT}

The studies by Carvalho et al. (2019) demonstrate that, a patent is a protection for the invention not to be misused. Furthermore, it guarantees the inventor the financial return for his intellectual work.

With the patent filed and approved, the inventor can commercially benefit from its production.

According to Soares and Kauffman (2018), for organizations, a patent contributes to the company's image, adding the concept of an innovative company. In addition, the organization has a temporary monopoly on the invention, gaining a greater share of the market.

\section{DIFFICULTIES AND CHALLENGES IN BRAZII}

Brazil still faces many problems when it comes to intellectual property. for example, how to carry out a search or how to register patents is unknown to most Brazilian companies.

According to Santos et al. (2018), there is a lack of support in disseminating the benefits that intellectual property ensures to entrepreneurs.

In addition, there is no policy of primary care for patents, which makes Brazilian entrepreneurs motivated to support or carry out innovation and invention.

\section{STATISTICS ON INTELLECTUAL PROPERTY IN BRAZII}

In Brazil, the responsible body is the National Institute of Industrial Property (INPI). It is linked to the Ministry of Industry, Foreign Trade and Services, with headquarters and jurisdiction in the Federal District, and its main purpose is to implement, at the national level, the rules that regulate industrial property, in view of its social, economic, legal and technical, and pronounce on the convenience of signing, ratifying and denouncing conventions, treaties, agreements and agreements on industrial property.

According to Industrial Property Indicators, in 2019, INPI obtained the following indicators:

- Received 28,318 patent applications. The number of orders increased $2.8 \%$ compared to the previous year;

- Patents for invention and utility models grew by $2.2 \%$ and $9.1 \%$, respectively;

- Certificates of addition fell by $9.4 \%$;

- Invention patent filings by residents grew by $9.7 \%$ compared to 2018 ;

- In relation to industrial designs, the total of 6,432 requests in 2019 represented an increase of $5.3 \%$ compared to 2018;

- With respect to brands, in 2019, INPI received 245,154 requests, which represented an increase of $19.9 \%$ compared to 2018;

- 16 applications for geographical indications were filed in 2019;

- 3,049 applications for registration of computer programs were filed, a figure $21.4 \%$ higher than that observed in the previous year;

- Three applications for registration of integrated circuit topographies were submitted in 2019 , demand equal to the year 2018 .

\section{INTELLECTUAL PROPERTY}

The research by Colomboa (2019) states that as innovation advances, it is important to protect intellectual works, valuing true inventors.

World Intellectual Property Organization (WIPO) defines intellectual property as the sum of rights relating to literary, artistic and scientific works, interpretations by performing artists and performances by performing artists, phonograms and broadcasting, inventions in all domains of human activity, scientific discoveries, industrial designs and models, industrial, commercial and service brands, as well as commercial firms and commercial names, protection against unfair competition and all other rights inherent to intellectual activity in the domains industrial, scientific, literary and artistic. 
To facilitate understanding, intellectual property is divided into 3 types:

Copyright: related to a person's intellectuality, copyright is subjective and has no industrial application. Examples: drawings, paintings, sculptures, books, conferences, scientific articles, music, films, photographs, software, among others; Industrial Property: related to industrial activities, Examples: industrial models, brands, industrial designs, geographical indications, industrial secrets and repression of unfair competition.

Sui Generis Protection: involves integrated circuit topography, cultivate and traditional knowledge.

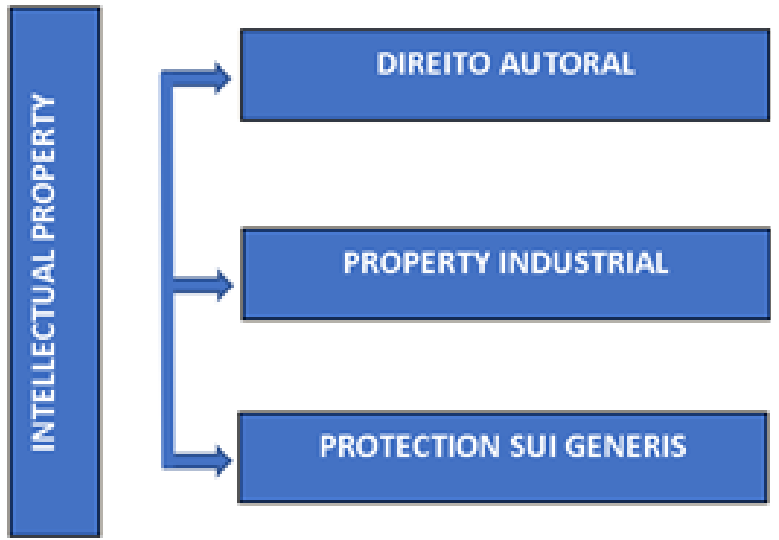

\section{Figure 1: Intellectual property model used in Brazil}

Sources: https://www.gov.br/inpi/pt-br/composicao/ arquivos guia empresario iel-senai-e-inpi.pdf.

\section{CONCLUSIONS}

The innovation process will be increasingly valued around the world. Believe me: there is still more to discover, invent and innovate.

All developed countries invest in intellectual property. There is a consensus on the benefits that the protection of new technologies and products economically favors a country.

For emerging countries, the policy to support innovation and protection of intellectual property must be a priority. Some patent applications can take more than 3 years in Brazil.

Companies need to have tools that facilitate access to information faster and more securely.

\section{REFERENCES:}

[1] DIANA, D. M. J. J. (2010). A caminho da inovação: proteção e negócios com bens de propriedade intelectual: guia para o empresário. IEL.

[2] da Silva, Davi N, Vieira, Raimundo K, Vieira, Adalena K, \& de Santiago, Miriam. (2016). Optimización del Proceso de Innovación para Proyectos Internos en las Empresas. Información tecnológica, 27(3), 119-130. https:// dx. doi. org/10.4067/S0718-07642016000300011

[3] Erber, F. S. (2004). Innovation and the development convention in Brazil. Revista Brasileira de Inovação, 3(1), 35-54.

[4] da Silva, M. B., \& Rodrigues, J. L. Electric vehicles: history, barriers and possibilities in Brazil and amazon. Amazon Live journal,v.2,n.4, p. 1-13,2020.

[5] Carvalho, B. C. C. B., \& Santos, M. R. D. M. C. (2019). The international patent classification: Description and importance. REVISTA GEINTEC-GESTAO INOVACAO ETECNOLOGIAS, $9(1), 4798-4808$

[6] Santos, T. S., Chais, C., Ganzer, P. P., \& Olea, P. M. (2018). Technology transfer between universities and companies: Two cases of Brazilian universities. RAI, 15(1), 2 .

[7] e Colomboa, D. G. (2019). Brazilian Innovation Tax Policy and International Investment: Evidence from United States Multinationals and International Patent Applications Política Fiscal de Inovação Brasileira e Investimentos Internacionais: Evidências de Multinacionais Norte-Americanas. Análise, 37(74), 61-90.

[8] SOARES, Marcelo Negri; KAUFFMAN, Marcos Eduardo. Intellectual property law in the fourth industrial revolution: trade secrets risks and opportunities. Revista Jurídica,v.4,n.53,p. 199-224,2018. 